\title{
An Investigation into the Possibility of Producing Fuel Ethanol from Forest Anchomanes (Anchomanes Difformis (Bl.) ENGL.)
}

\author{
Oyelayo Ajamu Oyedele* Olusegun Adeoti Opeyemi Oluremi Adeyanju \\ Department of Agricultural and Bio-Environmental Engineering \\ The Federal Polytechnic, Ado Ekiti, Ekiti State, Nigeria
}

\begin{abstract}
One of the factors responsible for the slow growth of the Nigerian Biofuel Programme is the concern trailing the use of cassava, a crop that has food, feed and industrial value in Nigeria, for fuel production. As an alternative feedstock, this study investigates the possibility of producing fuel ethanol from forest anchomanes (FA), Anchomanes difformis (Bl.) Engl., a plant that has no food and feed value in Nigeria. Results showed that FA tubers were rich in carbohydrate, between 70 and Sarkar, $2011 \%$. The stoichiometric ethanol content of FA varied from 0.032 to $0.054 \mathrm{~kg} \mathrm{~kg}^{-1}$ of fresh tubers, while the crude FA ethanol had a mean density of Nwachukwu and Simonyan, $20151.2 \mathrm{~kg} / \mathrm{m}^{3}$ at $20^{\circ} \mathrm{C}$. This suggests that FA has some potential for fuel ethanol production. This finding is useful to countries in the West African sub-region where FA is found.

Keywords: Forest anchomanes tuber; Forest anchomanes starch; Ethanol content; Ethanol density; Nigeria biofuel programme
\end{abstract}

DOI: $10.7176 / \mathrm{JETP} / 10-1-03$

Publication date: January $31^{\text {st }} 2020$

\section{Introduction}

Multiple factors explain why biofuel production is gaining global attention. These include rising crude oil prices which imposes foreign exchange burdens, the desire to be energy secured and eliminate oil dependency, climate change threats, increasing rural poverty, to improve urban air quality, to increase the share of renewable energies in the total energy mix, the realisation that crude oil is finite, and to achieve sustainable development, job as well as wealth creation.

To ensure that Nigeria becomes a biofuel producer and user, the Nigerian Biofuel Policy and Incentives (NBPI) was released in 2007 following a Biofuel Programme that started in 2004. It was not until 2008 that the country joined the league of biofuel users through e-blend fuel import when the then Federal Government agreed to start with $5 \%$ ethanol addition (E5) to Premium Motor Spirit (PMS) for automotive use (Adeoti, 2010). The policy document has articulated the production of biofuel from cassava, sugarcane, cellulose-based biomass, and any other crops as may be approved by the Biofuel Energy Commission. Its target is to reduce the country's dependence on imported PMS, cut environmental pollution resulting from fossil fuel use, and create jobs. The Nigerian Biofuel Programme creates a deliberate action plan to link the downstream petroleum sector with the agricultural sector of the economy. The NBPI approved fuel ethanol consumption in Nigeria at $10 \%$ blend ratio of fuel ethanol (E10) with PMS. At $10 \%$ blend ratio, the NBPI estimated that the Nigerian market requires $1.3 \times 10^{6} \mathrm{~m}^{3}$ of fuel ethanol annually, projected to increase to $2.0 \times 10^{6} \mathrm{~m}^{3}$ per year by 2020 . While both E5 and E10 PMS are suitable for use without any engine modifications (İçöz et al., 2008), the concern in Nigeria is that higher levels could harm existing or conventional automobile engines. Consistent with the NBPI and for clarity purposes, fuel ethanol is defined as hydrous or anhydrous bioethanol denatured for use as a motor fuel, and biofuels as fuels obtained from biomaterials.

At the global level, over $80 \%$ of the primary energy being consumed is derived from fossil fuels, and roughly $58 \%$ of it is being consumed in the transportation sector (Escobar et al., 2008). At present Nigeria is a major crude oil producing (Table 1) and exporting country and has enormous potentials of becoming a major player in the global biofuels production and trade (Abila, 2010). The oil sector provides $95 \%$ of Nigeria foreign exchange earnings and $80 \%$ of its budgetary revenues (Global Edge, 2017). Proceeds from oil accounted for $8.60 \%$ of the aggregate real GDP in 2018 and non-oil for the balance (National Bureau of Statistics (NBS), 2019). As illustrated in Table 2, Nigeria depends largely on refined PMS importation. Notwithstanding this, the Federal Government has emphasised its determination to reduce the importation of refined petroleum products by Arshad et al., $2018 \%$ by December 2018 and stop its importation by 2019 (Kachikwu,2017; Eboh, 2017, NNPC, 2018). With Nigeria being a crude oil producer, rising unemployment, increasing cost of refined petroleum products import, and mounting public criticisms are some of the factors pressing the federal government to stop refined petroleum products importation. However, an implication of this ban is that the E10 component of the PMS will have to be sourced locally. Nigeria, which has entered the second phase of the Biofuel Production Programme implementation, intends to achieve a $100 \%$ domestic production of biofuels by 2020 (Federal Republic of Nigeria, 2007). As at 2017, the annual ethanol demand in Nigeria was $1.7 \times 10^{6} \mathrm{~m}^{3}$ (Table 3), while local production was $9.0 \times 10^{3} \mathrm{~m}^{3}$ per year (Table 3). As shown in Table 3, the amount of ethanol produced in Nigeria was barely able to meet 3 to $4 \%$ of the requirements of the manufacturing sector alone. At present the Nigerian National Petroleum Corporation 
(NNPC) is the sole importer of refined petroleum products in Nigeria, importing fuel ethanol to blend locally produced PMS (Ben-Iwo et al., 2016).

Twelve years after making the NBPI public, one of the factors responsible for the slow growth of the Nigerian Biofuel Programme is the concern trailing the use of agricultural crops that have food, feed and industrial value for fuel production. The concern is that this could cause ripple effects on food security, exacerbating hunger and poverty. Cassava mentioned in the NBPI has food, feed and industrial value in Nigeria and also to a lesser extent sugarcane. An analysis of the proposed fuel ethanol projects in Nigeria revealed that ten of those projects were cassava-based, eight sugarcane-based and the remaining two sweet sorghum-based (Ohimain, 2010). Besides this, in 2017, the NNPC signed a Memorandum of Understanding (MoU) with the Government of Ondo State to establish a $65 \times 10^{3} \mathrm{~m}^{3}$ per annum cassava-based biofuel plant in Okeluse, Ondo State (Nnodim, 2017). These projects are yet to commence. Traditionally, sugarcane is grown by smallholder farmers for chewing as juice and for livestock feed (Ben-Iwo et al., 2016). In Nigeria, sugarcane-based fuel ethanol production poses very little threat to the local economy, as the crop does not serve as a daily food like sorghum and cassava (Galadima et al., 2011). Although the Nigerian Sugar Master Plan seeks to make Nigeria achieve self-sufficiency in its sugar requirements and reduce dependency on sugar imports, the country still commits between 450 and US\$600 x $10^{6}$ annually on sugar importation. The influx of cheaper refined sugar has contributed to the death of many sugarcane plantations in Nigeria (Abila, 2010). This situation has encouraged the much attention being shifted to cassava for fuel ethanol production. There is no doubt that if all the cassava and sugarcane produced in Nigeria is diverted to ethanol production (Table 4), this is capable of meeting the country's ethanol requirements (Table 3 ). But this is unrealistic. Experiences from the 2007 - 08 global food crisis have shown that biofuels production from food crops altered the food and feed markets by way of increasing demand for crops and placing rising prices on crops (Naylor et al., 2007; Stein, 2007; Dong, 2007; Dale, 2008; de Fraiture et al., 2008; Ewing and Msangi, 2008; Elliott, 2008; Sugrue, 2008; Timilsina and Shrestha, 2010; Sorda et al., 2010). It is therefore likely

Table 1: Crude oil and condensate production in Nigeria

\begin{tabular}{|c|c|c|c|c|c|c|c|c|c|}
\hline Year & 2018 & 2017 & 2016 & 2015 & 2014 & 2013 & 2012 & 2011 & 2010 \\
\hline $\begin{array}{llr}\text { Average } & & \text { daily } \\
\text { production } & (\mathrm{x} & 10^{6} \\
\text { barrels/day) } & & \\
\end{array}$ & 1.92 & 1.89 & 1.83 & 2.12 & 2.19 & 2.19 & 2.27 & 2.37 & 2.45 \\
\hline $\begin{array}{l}\text { Annual production (x } \\
10^{6} \text { barrels/year) }\end{array}$ & 699.51 & 690.01 & 670.00 & 773.46 & 798.54 & 800.49 & 852.78 & 866.25 & 896.04 \\
\hline
\end{tabular}

Sources: (NNPC, 2010, 2011, 2012, 2013, 2014, 2015, 2016, 2018 and NNP, 2019)

Table 2: PMS situation in Nigeria

\begin{tabular}{lcllllllll}
\hline Year & 2018 & 2017 & 2016 & 2015 & 2014 & 2013 & 2012 & 2011 & 2010 \\
\hline E10 PMS* consumption $\left(\times 10^{6} \mathrm{~m}^{3}\right)$ & 18.69 & 13.31 & 11.00 & 8.06 & 6.91 & 7.82 & 8.39 & 8.04 & 9.09 \\
Importation (\%) & 96.6 & 90.1 & 89.6 & 95.8 & 90.0 & 78.0 & 83.8 & 27.6 & 87.1 \\
Local production** (\%) & 3.4 & 9.9 & 10.4 & 4.2 & 10.0 & 22.0 & 16.2 & 72.4 & 12.9 \\
Average daily consumption $\left(\mathrm{x} 10^{3}\right.$ & 51.19 & 36.48 & 30.05 & 22.08 & 18.94 & 21.43 & 22.93 & 22.03 & 24.91
\end{tabular}
$\left.\mathrm{m}^{3}\right)$

*Indicates Premium Motor Spirit (or Gasoline) with $10 \%$ fuel ethanol by volume

**Nigeria has a total installed refining capacity of 445,000 barrels per day. As at the end of 2015, the country had $37 \times 10^{9}$ barrels of proven crude oil reserves, making it the second largest in Africa after Libya.

Sources: (NNPC, 2016; 2017, 2019 and U.S. Energy Information Administration, 2016)

Table 3: Ethanol demand in Nigeria

\begin{tabular}{llcll}
\hline Sector & Description & $\begin{array}{l}\text { Annual demand (x 106 } \\
\left.\mathrm{m}^{3}\right)\end{array}$ & Reference(s) & $\begin{array}{l}\text { Implementation } \\
\text { status** }\end{array}$ \\
\hline $\begin{array}{l}\text { Transportation* } \\
\text { Household }\end{array}$ & $\begin{array}{l}\text { E10 PMS blend } \\
\text { Ethanol-based } \\
\text { household cooking and } \\
\text { lighting fuel to replace } \\
\text { kerosene fuel }\end{array}$ & 3.75 & $\begin{array}{l}\text { (FGN, 2007) } \\
\text { [Ben-Iwo et } \\
\text { al., 2016 and } \\
\text { Ohimain, }\end{array}$ & $\begin{array}{l}\text { The programme is yet } \\
\text { to commence }\end{array}$ \\
$\begin{array}{l}\text { Manufacturing } \\
\text { Total }\end{array}$ & Industrial use/products & $\begin{array}{l}\text { 2010) } \\
\text { (Essiet, 2017) }\end{array}$ & On-going \\
\hline
\end{tabular}

*Includes stationary users such as private electricity generators, etc.

** Authors' contribution

****Between 96 and $97 \%$ were imported into Nigeria from various sources 
Table 4: Ethanol production from cassava and sugarcane in Nigeria

\begin{tabular}{|c|c|c|c|c|}
\hline Crops & $\begin{array}{l}\text { Production (tonnes, } \\
\text { t) } \\
\text { (average: } 2010 \text { - } \\
\text { 2017)* }\end{array}$ & $\begin{array}{l}\text { Area harvested (hectares, ha) (average: } \\
\qquad 2010-2017)^{*}\end{array}$ & $\begin{array}{c}\text { Ethanol } \\
\text { yield } \\
\left(\mathrm{x} 10^{6} \mathrm{~m}^{3}\right)\end{array}$ & Conversion factor \\
\hline Cassava & $52,850,513$ & $5,795,394.25$ & 7.24 & $\begin{array}{c}7.3 \mathrm{~kg} \text { per } 10^{-3} \\
\mathrm{~m}^{3 * *}\end{array}$ \\
\hline Sugarcane & $1,226,873$ & $71,261.13$ & 0.09 & $\begin{array}{l}14.3 \mathrm{~kg} \text { per } 10^{-3} \\
\mathrm{~m}^{3 * * *}\end{array}$ \\
\hline Total & & & 7.33 & \\
\hline
\end{tabular}

that the prices of gari and other cassava cassava-based derivatives may increase as a result of increased cassava prices. Estimates are that the cost to the gari consumers might increase by about 10 to $15 \%$ due to higher cassava prices. Roughly two-thirds of fresh cassava produced in Nigeria are converted to gari (Amoah et al., 2010, Adeoti et al, 2009), with the remaining one-third going into industrial and other applications. Besides this, a federal government policy has also pushed for a 10 per cent inclusion of cassava in bread to reduce wheat flour import. Food prices volatility has the greatest effect on poor households (Naylor et al, 2007) and net-food-purchasing households (Dongl, 2007). However, while expansion may be considered an option, it is important to highlight that Nigeria's arable land is limited and the country does not even have the climate to grow cassava and sugarcane in all the agro-ecological zones due to soil, land, water, and ecosystem requirements.

In the case of Nigeria where governance structures are weak and inadequate, crop-based biofuels production may alter the prices of agricultural food crops through direct and indirect channels, exacerbating hunger and poverty. Since the use of cassava for fuel ethanol production may threaten the food security of Nigeria, looking for a replacement becomes very vital in promoting the Nigerian Biofuel Programme. This study therefore investigates the possibility of producing fuel ethanol from forest anchomanes (FA), Anchomanes difformis (Bl.) Engl. Being a less researched plant, the study takes a detailed look at the proximate, phytochemical and elemental properties of FA tubers with a view to suggest its use for fuel ethanol production. FA is a plant that grows in the southern part of Nigeria which at present has no food and feed value. The finding of this study is also relevant to countries in the West African sub-region where FA is found.

\subsection{Existing use of FA tubers}

While the medicinal use of FA (leaves, stems, and tubers) has been well reported in the literature, there is a paucity of information on the use of this plant for fuel ethanol production. FA has been used to treat cough, ulcer, dysentery, and as an eyes drop for the treatment of river blindness (Okpo et al., 2011). An aqueous extract of the tubers has been used to treat oedemas, kidney pains, as diuretic for the treatments of jaundice, urethral discharge, as an antidote for poison (Akinkurolere, 2007; Olawale et al., 2013; Ovuakporie et al., 2015; Agyare et al., 2016), and has also been reported in the cure of dysentery (Oyetayo, 2007). Traditionally, FA has also been used to treat diabetes, tuberculosis, malaria, and as an oral and anal lesions (Bero et al., 2009, Jacob and MacDonald, 2015). Also, Jacob and MacDonald (2015) found FA to reduce serum concentrations of some sex hormones linked to pathogenesis of uterine fibroids, suggesting its possible use in uterine myomata management. As antimicrobial (Ovuakporie et al., 2015), powder from FA tubers has also been found to be toxic on storage beetles (Akinkurolere, 2007). Agyare et al. (2016) found that FA had some antioxidant and anti-inflammatory properties. The presence of phytochemicals has been held responsible for plants medicinal use (Ifemeje et al., 2014 and Egwurugwu et al., 2017). However, no fuel application has been reported.

\subsection{Ethanol as a Fuel}

Ethanol production as beverages is not new in Nigeria. It has been part of the livelihood systems of people living in the Niger Delta and those in the riverine areas of the southwestern states of Nigeria. The ethanol produced by various small-scale processors are used by local industries and consumed as liquor (Abila, 2010). However, there is no history of its use for mobility in Nigeria before 2008 when the country joined biofuel users through e-blend fuel import. Using ethanol as a fuel is potentially renewable and carbon neutral (because biofuels recycle atmospheric carbon dioxide), and can serve as a petroleum alternative that provides large-scale economic, national security and environmental benefits to Nigeria. The use of ethanol in the automobile industries is not new as it has been designated for use as a fuel from the early days (İçöz et al., 2008). Globally, ethanol is the most utilised nonfossil fuel for mobility (Oke et al., 2016). Between 2000 and 2017 global fuel ethanol production rose from $28 \mathrm{x}$ $10^{6} \mathrm{~m}^{3}$ in 2000 (Içёz et al., 2008) to $101.49 \times 10^{6} \mathrm{~m}^{3}$ in 2017 (Renewable Fuels Association, 2019). In 2018, total global fuel ethanol production was $108.13 \times 10^{6} \mathrm{~m}^{3}$ (Renewable Fuels Association, 2019), with Brazilian sugarcane-based fuel ethanol contributing $27.7 \%, 56.2 \%$ from the corn-based fuel ethanol in the US, $3.7 \%$ from the corn and wheat-based fuel ethanol in China, and 5.0\% from the EU grains, molasses and sugarbeet-based fuel 
ethanol (Renewable Fuels Association, 2019). Global fuel ethanol production is expected to hit $134.5 \times 10^{6} \mathrm{~m}^{3}$ by 2024 (OECD/FAO, 2015).

Compared with that of PMS of 80 , ethanol has a motor octane number of 98 and has a lower vapour pressure than PMS (Adeoti, 2010). $1 \mathrm{~m}^{3}$ of ethanol contains roughly two-thirds the energy of a $1 \mathrm{~m}^{3}$ of PMS (Naylor et al, 2007; Timilsina and Shrestha, 2010; Crago and Khanna, 2013). In the PMS additives market, ethanol and methyltertiary butyl ether (MTBE) are close substitutes (Anderson and Elzinga, 2014). With the phasing out of MTBE (an octane booster which replaced lead) as a fuel additive due to environmental concerns, ethanol provides a good substitute for MTBE and also serves as a PMS extender and octane enhancer. Ethanol can be blended with PMS at the rates of 5, 10, and $85 \%$ (İçöz et al., 2008), as well as at 20 to $25 \%$ (Goldemberg, 2008). There are flexible fuel vehicles which are capable of running with blends from E0 to E100 (Elliott, 2008, Goldemberg, 2008). These vehicles are common in some countries, for example, US and Brazil. Ethanol has a significant higher heat of vapourisation, which helps to provide a cooling effect, thereby lessening engine knock (Renewable Fuels Association, 2018). As noted by Goldemberg (Goldemberg, 2008), ethanol-fuelled engines are about $15 \%$ more efficient than gasoline-fuelled engines. Adding ethanol to PMS increases the octane property of the fuel blend, thereby protecting against engine knock (Larsen, 2009). Ethanol has also been reported in the literature as capable of contributing to decrease in brake specific energy consumption of spark-ignition engines using the electronic fuel injection system (Barakat et al., 2015). Because ethanol contains oxygen, PMS-ethanol blends produce less carbon monoxide when compared with the conventional PMS (Ohimain, 2010). Despite these merits, ethanol also has some drawbacks. The ethanol itself could cause skin and eye irritation (Arshad et al., 2018), and can induce dry-corrosion of aluminum alloys (Japan Automobile Manufacturers Association, 2009). Breathing vapours of ethanol can cause headaches, dizziness and nausea (Renewable Fuels Association, 2011). Although less harmful to the environment and human health compared with formaldehyde when PMS is burnt, acetaldehydes are produced from engines using neat or blended ethanol (Goldemberg, 2008). With increasing global demand for fuel ethanol and the need to replace cassava with a plant that has no food and feed value, investigating the possibility of producing fuel ethanol from FA tubers becomes very vital to support the growth and sustainability of the Nigerian Biofuel Programme.

\subsection{About the Plant, FA, Anchomanes difformis (Bl.) ENGL}

The narrations presented below on FA plant were obtained from the literature and field observations conducted between September and June 2018.

FA, Anchomanes difformis (B1.) ENGL, of the family of Araceae, is an herbaceous plant with a huge divided spathe leaf and prickly stem that grows from a horizontal underground tuber. The plant, which is annual, is naturally occurring in the forests of West Africa, especially in the southern guinea savanna and the humid forests. The plant is adapted to temperatures ranging from 30 to $35^{\circ} \mathrm{C}$, and to rainfall of 1.0 to over $2.0 \mathrm{~m}$ annually. Stem diameter, which tapers upward, can be up to $0.05 \mathrm{~m}$ at $0.5 \mathrm{~m}$ aboveground. Vertical growth (or plant height) is slow in the first 3 weeks after sprouting (between 0.05 and $0.15 \mathrm{~m}$ per week), and can be rapid in the last 3 to 4 weeks (between 0.4 and $1.0 \mathrm{~m}$ per week). Vertical growth stops when the leaves are fully spread, although an incremental vertical growth can still occur (between 0.01 and $0.03 \mathrm{~m}$ per week) before it finally stops after two to three weeks. It is assumed that starch accumulation begins after the full spread of leaves. From sprouting to when leaves are fully spread could vary from 6 to 8 weeks. Depending on field conditions and the number of shoots, aboveground plant height to where the stem first branched could reach $2.19 \mathrm{~m}$, or more. Vertical height ranging from 0.8 to $2.0 \mathrm{~m}$ has also been reported (Olanlokun et al., 2017).

Similar to cassava (Adeoti, 2010, Akinoso and Olatunde, 2014), the fresh tubers of FA (Figure 1) do not store for long before they rot within 3 to 5 days after harvest. An important attribute of FA is the production of large horizontal underground storage tubers, which continuously accumulate without decaying. These horizontal tubers have diameters varying from 0.04 to $0.12 \mathrm{~m}$, extending over $0.6 \mathrm{~m}$, and weighing up to Nwachukwu and Simonyan, $2015 \mathrm{~kg}$. Olanlokun et al. (2017) and Jacob and MacDonald (2015) have reported that the tubers could also reach 0.5 to $0.8 \mathrm{~m}$ long and 0.1 to $0.2 \mathrm{~m}$ in diameter. Depending on the methods used, peels of fresh FA could amount to $26.5 \%$ of the fresh tubers, higher than that of cassava, $15 \%$ (Adeoti, 2010). The stored carbohydrates in the tubers support the growth of FA plant in the beginning of raining season, usually March or April following break in dormancy. No commercial use of FA has been reported, except the traditional use of the plant to cure ailments as reported earlier. Because the plant is less researched, data on soil requirements and biomass yield (belowground and aboveground) is lacking. Information on the population of FA that have produced an appreciable stock of carbohydrates or when it begins storing starch and other fermentable carbohydrates in the tubers after sprouting is also unknown. Nonetheless, FA tubers may be harvested in 5 to 6 months, usually as from September. At present the massive underground tubers mostly cause obstruction to disc ploughs during tillage operations and hoes during heaping or ridging operations.

In order to suggest the possibility of FA tubers for fuel ethanol production, this study takes a detailed look at the elemental, proximate, phytochemical, and starch contents of FA tubers. It also examines the ethanol content 
and the density of the crude FA ethanol. The need to quantitatively understand these properties of FA tubers has informed the materials and methods adopted by this study.

\section{Materials and Methods}

\subsection{Material Sourcing and Sample Preparation}

The tubers of FA used in this study were sourced from the forests around the departmental farm. The first round of tubers used was collected from three locations in September 2017 following leaf senescence. The sites for the plant were located and carefully dug out manually in its natural state in the soil to avoid damages. Tubers were harvested to a depth of $0.3 \mathrm{~m}$. All tubers in each excavation were collected and weighed. The uprooted tubers were first sifted by hand and then brought to the laboratory where they were washed with water to remove attached soils and roots. It was further rinsed with water in order to properly remove any other plant and soil materials. Weight and measurement of other physical parameters were taken and recorded. To test whether the elemental, proximate, phytochemical, and starch contents varied across the horizontal length of the tubers, three sampling areas were carefully located on the tubers to represent the three stages of tuber storage development. This is because, as explained earlier, FA plants do continuously store in their tubers without decay which seems common to the Araceae family. Sample one (S1) represented the part of the tubers that was very recent, say between 1 and 2 years old. This part had yellow colour. Sample two (S2) represented the intermediate part, say between 3 and 5 years old. This part was light pink in colour, while sample three (S3) represented the part of the tubers assumed to be older than 5 years. This part was pink in colour. The age classification is rough, because of a dearth of scientific information on FA plants. However, one point to note is that the colour differences along the horizontal dimension of the tubers had only helped to suggest possible variations in the age of storage in the tubers. Since this may have implications for starch parameters, this study examines data from the three different storage areas in the tubers and links these data to when tubers were harvested.

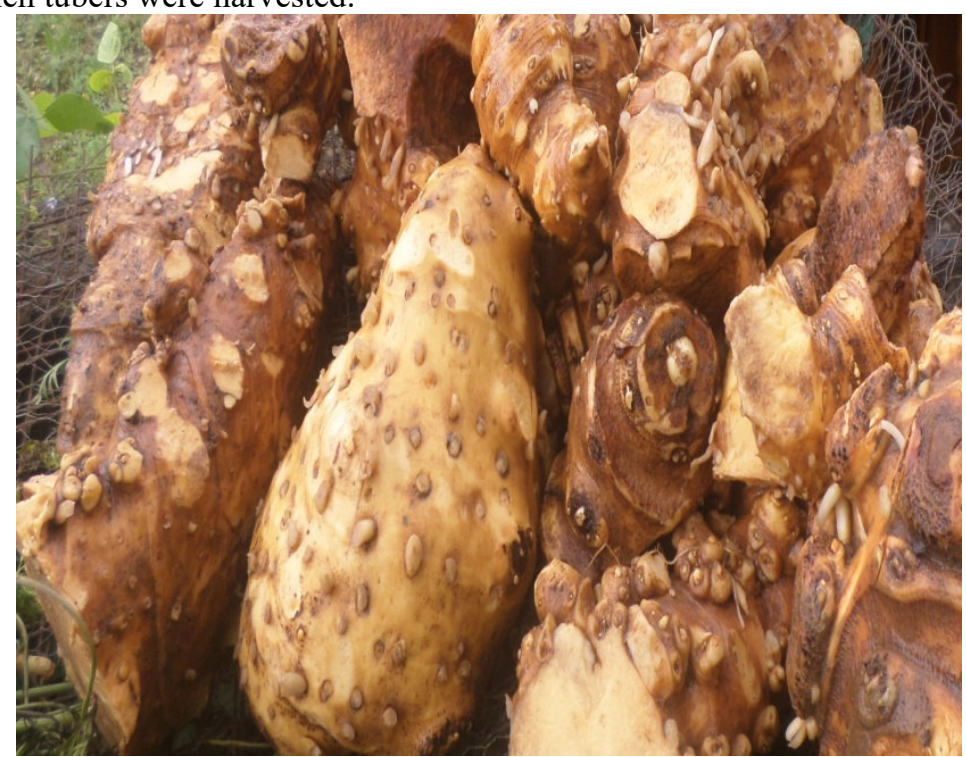

Fig. 1: Fresh FA tubers

\subsection{Elemental and Proximate Analyses of FA Tubers}

The fresh samples collected in September 2017 were sliced into tiny pieces and oven dried at $65^{\circ} \mathrm{C}$ to a constant weight, milled into powder and kept in air tight nylon to prevent moisture re-absorption. The samples were assayed for elemental and proximate contents. The elemental analysis was carried out at the 5SDH Tandem Accelerator Laboratory, Centre for Energy Research and Development (CERD), Obafemi Awolowo University (OAU), IleIfe, Osun State, Nigeria, while the proximate analysis was carried out at the Central Research Laboratory (CRL) of the Federal Polytechnic, Ado Ekiti, Nigeria.

\subsubsection{Elemental analysis}

The Proton-Induced X-ray Emission (PIXE) technique was used to determine the concentration of elements in FA tuber samples. The analytical facility used a $3.0 \mathrm{MeV}$ proton beam. Details of the procedure followed are as described by (Alatise et al., 2009).

2.2.2 Proximate analysis

Moisture content, ash, crude fat, crude fibre, protein and carbohydrate were determined using the test methods of the (Association of Official Analytical Chemists (AOAC), 1990). 


\subsubsection{1 pH, Moisture, Density, Starch Content, And Phytochemical Screening Of Fa Tubers}

Another round of fresh FA tubers was harvested in March 2018 to carry out the pH, moisture, tuber density determination, starch content, and phytochemical screening. These analyses were carried out in the Processing Laboratory of the Department of Agricultural and Bio-Environmental Engineering (ABE), the Federal Polytechnic, Ado Ekiti, Nigeria.

\section{pH analysis}

$5 \mathrm{~g}\left(1 \mathrm{~g}=10^{-3} \mathrm{~kg}\right)$ of fresh FA tubers was weighed, milled and added to $20 \mathrm{~mL}\left(1 \mathrm{~mL}=10^{-6} \mathrm{~m}^{3}\right)$ of deionised water in a test tube. The mixture was shaken for $5 \mathrm{~min}$ using an electric shaker, and centrifuged (G-Bosch Centrifuge model Nwachukwu and Simonyan, 2015 0D) at $4000 \mathrm{rpm}$ for $5 \mathrm{~min}$. The supernatant was tested for acidity and alkalinity using a digital $\mathrm{pH}$ meter tester (Cyber Tech $\mathrm{PH}-107$ digital meter tester). $\mathrm{pH} 4.0$ and $\mathrm{pH} 9.2$ buffer solutions were used to calibrate the $\mathrm{pH}$ meter tester.

\section{Moisture content (MC) analysis}

The gravimetric method of Nwabanne (2009) was used to determine the moisture content of fresh FA tubers. The moisture content (MC) on a wet basis was obtained from Equation 1.

$$
\mathrm{MC}_{\text {wet basis }}=\frac{m_{i}-m_{f}}{m_{i}} \times 100 \%
$$

Where, $\mathrm{m}_{\mathrm{i}}$ is the initial mass $(\mathrm{kg})$, and $\mathrm{m}_{\mathrm{f}}$ is the final mass $(\mathrm{kg})$.

\section{Tuber density determination:}

Various sections of unpeeled FA tubers were cut and weighed using an Electronic Balance (MP10001) and the volume determined using the water displacement method. The density of the unpeeled fresh FA tubers was obtained from Equation 2.

$$
\text { Density }=\frac{\text { Mass }}{\text { Volume }}\left(\mathrm{kg} / \mathrm{m}^{3}\right)
$$

\subsection{Theoretical starch content:}

The perchloric acid - anthrone reagent method as described by Hodge and Hofreiter (1962) was used to determine the starch contents of FA tuber samples. The values obtained were assumed as the maximum (or theoretical) starch content of FA tubers.

\subsubsection{Phytochemical (or antinutrient) screening}

Using quantitative approaches, the phytochemical (or antinutrient) properties of fresh FA tubers evaluated include total phenols, tannins, total flavonoids, phytates, oxalates, cardiac glucosides, alkaloids, and total saponins.

The Folin-Ciocalteu spectrophotometric method as described by Singleton et al. (1999) was used to measure the amount of phenols. The tannin content was determined according to the Folin-Ciocalteu method of Tambe and Bhambar (2014). The absorbance for test and standard solutions was measured against the blank at $725 \mathrm{~nm}$ using an Ultraviolet (UV)/Visible spectrophotometer. The aluminium chloride colorimetric assay described by Tambe and Bhambar (2014) was used to measure the total flavonoid content. The colorimetric method of Lolas and Markakis (1975) was used to determine the phytate content. The percentage phytic acid was calculated using Equation 3.

$$
\% \text { Phytic acid }=\frac{\text { Titre Value } x 0.001 \text { Shajeela et al } 2011 \times 1.19}{\text { weight of test sample }} \times 100
$$

The titrimetric method, which involved three major steps: digestion, oxalate precipitation, and permanganate titration, as described by Ifemeje et al. (2014) was used to determine the oxalate content. The amount of cardiac glycoside was determined using the aqueous sodium hydroxide - dinitro salicylic acid method of Ifemeje et al. (2014). Equation 4 was used to calculate the percentage cardiac glycoside.

$$
\% \text { Glycoside }=\frac{\text { (wt of filter paper }+ \text { Residue })- \text { Wt of empty filter paper }}{\text { wt of sample }} \times 100
$$

The alkaloid and total saponin contents were measured using the acetic in ethanol - ammonium hydroxide method as described by Ifemeje et al. (2014). The percentage alkaloid was calculated using Equation 5, while the percentage saponin was calculated using Equation 6.

$$
\% \text { Alkaloid }=\frac{W_{2}-W_{1}}{\text { Weight of sample }} \times 100
$$

Where, $\mathrm{W}_{1}$ is the weight of empty filter paper and $\mathrm{W}_{2}$ is the weight of empty filter paper + Alkaloid

$$
\% \text { Saponin }=\frac{W_{2}-W_{1}}{\text { Weight of sample }} \times 100
$$

Where, $\mathrm{W}_{1}$ is the weight of empty filter paper, and $\mathrm{W}_{2}$ is the weight of the filter paper + residue

\subsection{Starch extraction}

Starch was extracted from another round of fresh FA tubers harvested in March 2018. After cleaning as described 
earlier, the fresh tubers were peeled and weighed. $500 \mathrm{~g}$ of peeled sample was milled into pulp using a hand-held grater. Leal, $2014 \mathrm{~mL}$ of water was added to the pulp, agitated for 5 min using an electric shaker, and sieved using muslin cloth. Trial experiments carried out in September 2017 revealed that the starch granules would not settle quickly in water, therefore the mixture was centrifuged (using G-Bosch Centrifuge model 800D) at 4,000 rpm for $10 \mathrm{~min}$. The supernatant was decanted and the mucilage manually scrapped off. The resulting starch was dried in an oven at $50{ }^{\circ} \mathrm{C}$ until constant weight, weighed, and stored for ethanol content determination. Equation 7 was used to calculate the mean starch recovery ratio.

$$
\text { Mean starch recovery ratio }(\%)=\frac{\gamma}{\Upsilon} \times 100
$$

Where, $\gamma$ is the starch obtained $(\mathrm{kg})$, and $\mathrm{Y}$ is the theoretical starch content $(\mathrm{kg})$

\subsection{Ethanol content}

Starch is a polymer of glucose. Although the starch content in tuber crops varies, it nevertheless serves as a predictor of ethanol yield (Li et al., 2015). To produce ethanol, the starch present in tuber crops would have to be hydrolysed into sugar, and the sugar fermented by yeasts. Hydrolysis of starch may be done by acid or enzyme, in a continuous or batch process (Sánchez and Cardona, 2007, Leal, 2014). Since there is yet no documented process on how to produce ethanol from FA starch, a modified procedure of Ajibola et al. (2012), based on the batch enzymatic process, was used. At the experimental stage, the batch process seems reasonable to use, while the continuous process may be appropriate for use at the industrial scale. Compared with acid hydrolysis, enzymatic hydrolysis consumes less energy, requires mild environmental conditions, and is less corrosive (Sarkar, 2011). The steps involved in the batch - enzymatic production of the crude FA ethanol are:

- Cooking and liquefaction (50g dry mass of FA starch was mixed with $100 \mathrm{~mL}$ of distilled water at room temperature to obtain slurries with $50 \mathrm{~g}$ solids per $150 \mathrm{~g}$ slurry. Slurry pH was adjusted to 6.5 using 5.0 $\mathrm{N} \mathrm{H}_{2} \mathrm{SO}_{4}$ solution. After this, the slurry was mixed with $4 \mathrm{~mL}$ of $\alpha$-amylase and $0.84 \mathrm{~g}$ of $\mathrm{CaCl}_{2}$, and then liquefied in a water bath at $60{ }^{\circ} \mathrm{C}$ for $1 \mathrm{~h}$ with continuous stirring. After $1 \mathrm{~h}$, the slurry temperature was decreased to $30{ }^{\circ} \mathrm{C}$, and its $\mathrm{pH}$ adjusted to 5.0 with $5.0 \mathrm{~N} \mathrm{H}_{2} \mathrm{SO}_{4}$ solution);

- Saccharification (6 mL aqueous solution of amylo-glucosidase was added to the liquefied starch, stirred, and incubated at $55^{\circ} \mathrm{C}$ for $4 \mathrm{~h}$. After $4 \mathrm{~h}$, the slurry temperature was decreased to $30{ }^{\circ} \mathrm{C}$ );

- Fermentation (a culture of Saccharomyces cerevisiae yeast was prepared by mixing $5 \mathrm{~g}$ of yeast in $20 \mathrm{~mL}$ of distilled water at $30{ }^{\circ} \mathrm{C}$ for 20 min with continuous shaking. $5 \mathrm{~mL}$ was added to the filtrate before it was anaerobically incubated at $30^{\circ} \mathrm{C}$ for $72 \mathrm{~h}$. The commercial strain S. cerevisiae is widely used in fuel ethanol production (Quintero et al., 2015); and

- Distillation (although Pimentel and Patzek (2005) submitted that 3 distillations were required to obtain $95.0 \%$ ethanol, the fermented broth was filtered using muslin cloth and the filtrate passed through the distillation unit thrice at $80{ }^{\circ} \mathrm{C}$ and once at $78^{\circ} \mathrm{C}$, since ethanol boils at $78^{\circ} \mathrm{C}$ ).

The two enzymes used in this study, $\alpha$-amylase and amylo-glucosidase, were obtained from the Enzymology Laboratory, Department of Biotechnology, Federal Institute of Industrial Research, Oshodi, Nigeria in June 2018. The yeast, Saccharomyces cerevisiae, from Guangdong Guanghua Sci-Tech Co. Ltd, China, JHD ${ }^{\circledR}$, was obtained from a chemical supplier in Nigeria. It expires on 22 August 2020. The specific gravity of the crude ethanol was measured after distillation. The value of the specific gravity was used to determine the ethanol concentration from a standard curve prepared from known concentrations of ethanol (Ado et al., 2009). The process performance was evaluated based on crude ethanol recovery per mass of substrate (kg-ethanol $/ \mathrm{kg}$-substrate). Ethanol recovery ratio was determined using Equation 8 after Li et al. (Li et al., 2015). The basic fermentation equation is as stated in Equation 9.

$$
\text { Ethanol recovery ratio }=\frac{\sigma}{\eta} \times 100 \%
$$

Where, $\sigma$ is the crude ethanol obtained $(\mathrm{kg})$, and $\eta$ is the theoretical (or stoichiometric) ethanol content $(\mathrm{kg})$

$$
\mathrm{C}_{6} \mathrm{H}_{12} \mathrm{O}_{6}(\text { Glucose }) \quad \stackrel{\text { Yeast }}{=}=>2 \mathrm{C}_{2} \mathrm{H}_{5} \mathrm{OH}(\text { Ethanol })+2 \mathrm{CO}_{2}(\text { Carbon dioxide })+\text { Heat }
$$

2.5.1 Density of crude FA ethanol

Apart from being an important fuel quality indicator, an accurate determination of density is necessary for the conversion of measured mass to volume at a standard reference temperature. The International Organization for Standardization (ISO) 758 test method was adopted to measure the density of the crude FA ethanol. The measurement was done at $20^{\circ} \mathrm{C}$ using a $10 \mathrm{~mL}$ pycnometer. The density was calculated from the difference in mass between the full and the empty pycnometer and its known volume.

\section{Results and Discussion}

\section{$3.1 \mathrm{pH}$, moisture content, and density of fresh FA tubers}

The $\mathrm{pH}$ values of fresh FA tubers were within the range of 6 and 6.5 (Table 5), which are comparable with most starches used in ethanol production. Similar to other tuber crops (Adeoti, 2010 Nwabanne, 2009, Nwachukwu and 
Simonyan, 2015 , Adepoju and Adejumo, 2015), fresh FA tubers were also rich in moisture. This varied from 81 to Chao et al., 2017 per cent (Table 5). The unpeeled fresh tubers mean density, which is slightly higher than those of cassava, 10 Ocloo and Ayernor, $2010 \mathrm{~kg} / \mathrm{m}^{3}$ (Nwachukwu and Simonyan, 2015 ) and sweet potato, $1104 \mathrm{~kg} / \mathrm{m}^{3}$ (Teye and Abano, 2012), varied from 1200 to $1400 \mathrm{~kg} / \mathrm{m}^{3}$ (Table 5). The dry matter contents of FA tubers ranged from 11.97 to $17.04 \%$. The dry matter contents of FA tubers increased from S1 to S3.

\subsection{Proximate, theoretical starch content, and starch recovery}

FA tubers were rich in carbohydrate (Table 6). This is quite appreciable as the dry matter of most tubers is made up of between 60 and $90 \%$ carbohydrate. However, the low amounts of ash, crude fat, fibre and protein (Table 6) are typical of tuber crops. As illustrated in Table 7, S2 had the highest amount of starch. The theoretical starch content of FA tubers was substantial when compared with starches from other sources and higher than that of cassava (Table 8). In quantitative terms, drawing on the data in Table 7, the theoretical starch content of FA tubers varied from 0.056 to $0.095 \mathrm{~kg} \mathrm{~kg}^{-1}$ of fresh tubers (mean $\approx 0.074 \mathrm{~kg} \mathrm{~kg}^{-1}$ of fresh tubers). Table 9 illustrates the results of starch

Table 5: $\mathrm{pH}$, moisture content, and density of FA tubers harvested in March 2018

\begin{tabular}{llll}
\hline Parameter & \multicolumn{3}{c}{ Sample } \\
\cline { 2 - 4 } & $\mathrm{S} 1$ & $\mathrm{~S} 2$ & $\mathrm{~S} 3$ \\
\hline $\mathrm{pH}^{*}$ & $6.38 \pm 0.08$ & $6.18 \pm 0.26$ & $5.88 \pm 0.05$ \\
Moisture content* $(\%)$ & $86.80 \pm 1.76$ & $84.00 \pm 2.00$ & $81.60 \pm 1.67$ \\
Density** $\left(\mathrm{kg} / \mathrm{m}^{3}\right)$ & $1168.19 \pm 21.52$ & $1246.49 \pm 21.18$ & $1398.48 \pm 20.77$ \\
\hline
\end{tabular}

$*$ Number of replicates $(\mathrm{N})=5 ; * * \mathrm{~N}=3$; Mean \pm standard deviation

Table 6: Proximate composition of FA tubers harvested in September $2017(\%)(\mathrm{N}=3)$

\begin{tabular}{lllllll}
\hline Sample & Moisture content & Ash & Crude fat & Fibre & Protein & Carbohydrate \\
\hline S1 & $9.34 \pm 0.07$ & $4.39 \pm 0.02$ & $3.01 \pm 0.01$ & $3.78 \pm 0.02$ & $5.33 \pm 0.03$ & $74.15 \pm 0.05$ \\
S2 & $8.66 \pm 0.05$ & $5.03 \pm 0.03$ & $3.72 \pm 0.02$ & $4.06 \pm 0.05$ & $3.86 \pm 0.02$ & $74.67 \pm 0.04$ \\
S3 & $7.40 \pm 0.01$ & $7.23 \pm 0.03$ & $5.11 \pm 0.02$ & $6.31 \pm 0.01$ & $3.79 \pm 0.07$ & $70.16 \pm 0.05$ \\
\hline
\end{tabular}

Differences between the carbohydrate values were non-significant at $\mathrm{p}<0.05$ (by one-way ANOVA and a Tukey’s means test)

Table 7: Carbohydrate and starch content of FA tubers harvested in March $2018(\%)(\mathrm{N}=5)$

\begin{tabular}{lll}
\hline Sample & Carbohydrate & Starch content \\
\hline S1 & 74.34 & $62.50 \pm 0.35$ \\
S2 & 76.46 & $72.80 \pm 0.12$ \\
S3 & 72.24 & $70.98 \pm 0.20$ \\
\hline
\end{tabular}

Differences between the starch values $(\mathrm{S} 1-\mathrm{S} 3)$

were significant at $\mathrm{p}<0.05$ (by one-way

ANOVA and a Tukey's means test)

Table 8: Starch content of some agricultural crops or biomaterials

\begin{tabular}{lcl}
\hline Crop & Starch content (\%) & Reference(s) \\
\hline Sweet potato (Ipomoea batatas) & 20.1 & (Leal, 2014) \\
$\begin{array}{l}\text { Cocoyam (Xanthosoma } \\
\text { (Colocasia esculenta) }\end{array}$ & & \\
Water yam (Dioscorea alata) & $25-35$ & (Leal, 2014 and O'Hair, 1990) \\
Cassava (Manihot esculenta) & 16.7 & (Leal, 2014) \\
Corn (Zea mays) & $25-40$ & (O'Hair, 1990) \\
Sorghum (Sorghum bicolor) & $70-72$ & (Shapouri et al., 2006) \\
Yams ( Dioscorea spp) & $68-70$ & (Shapouri et al., 2006) \\
Wheat (Triticum aestivum) & $15-40$ & (O'Hair, 1990) \\
Brown rice (Oryza sativa) & 62.0 & (das Neves, et al., 2006) \\
Breadfruit (Artocarpus communis) & 60.0 & (das Neves, et al., 2006) \\
Acorn (or oak nut) & 67.9 & (Loos et al., 1981) \\
\hline
\end{tabular}


Table 9: Starch recovery from FA tubers harvested in March $2018(\mathrm{~N}=5)$

\begin{tabular}{llll}
\hline Sample & $\mathrm{S} 1$ & $\mathrm{~S} 2$ & $\mathrm{~S} 3$ \\
\hline Amount $\left(\mathrm{kg} \mathrm{kg}^{-1}\right.$ of fresh tubers) & 0.046 & 0.055 & 0.039 \\
Std dev & 0.98 & 1.02 & 0.99 \\
\hline
\end{tabular}

recovery. The obtained dry starch granules were slightly off white in colour, with no smell. Starch recovery was highest in S2 (Table 9), amounting to $0.055 \mathrm{~kg} \mathrm{~kg}^{-1}$ of fresh tubers, translating to starch yield of $6.5 \%$. The percentage starch content of S1 was the lowest possibly because of starch mobilisation for new shoot formation, while there was the possibility of starch conversion to fibre in S3 (Table 7).

As illustrated in Table 9, starch recovery from S3 was the lowest, possibly because starch granules were trapped in the fibre. As shown in Table 6, S3 had the highest fibre content. The results of starch extraction in Table 9 should be considered as indicative. It however affirms the availability of starch in FA tubers. The mean starch recovery ratio was $63.5 \%$. Starch recovery might have been affected by (i) grater/grating performance, (ii) sieving efficiency, and (iii) the manual removal of mucilage. These constituted activities that led to starch loss.

\subsection{Theoretical (or stoichiometric) ethanol content and ethanol recovery}

Drawing on the theoretical starch content data therefore, the stoichiometric ethanol content of FA varied from 0.032 to $0.054 \mathrm{~kg} \mathrm{~kg}^{-1}$ of fresh tubers (mean $\approx 0.042 \mathrm{~kg} \mathrm{~kg}^{-1}$ fresh tubers). This conversion was based on the assumption that $1 \mathrm{~kg}$ of starch completely hydrolysed would give $1.11 \mathrm{~kg}$ of glucose, and $1 \mathrm{~kg}$ of glucose would theoretically yield $0.511 \mathrm{~kg}$ of crude ethanol (Li et al., 2015, Ocloo and Ayernor, 2010), resulting into a maximum conversion efficiency of glucose to ethanol of $51.0 \%$ on a weight basis. The value 1.11 is the theoretical conversion factor of starch to glucose ( $\mathrm{Li}$ et al., 2015, Borglum, 1980). On the average, $1 \mathrm{t}$ of fresh FA tubers would yield $74.2 \mathrm{~kg}$ of starch or $82.4 \mathrm{~kg}$ of glucose. Therefore, the mean maximum ethanol yield translates to $42.11 \mathrm{~kg} \mathrm{t}^{-1} \mathrm{of}$ fresh FA tubers. The mean maximum (or stoichiometric) value does not take into account ethanol loss due to unhydrolysed starch and glucose utilised by yeast.

The mean ethanol recovery was $0.34 \mathrm{~kg} \mathrm{~kg}^{-1}$ of FA starch at $96.1 \%$ ethanol concentration. This translates to $0.34 \mathrm{~kg}$ per $9.93 \mathrm{~kg}$ of fresh FA tubers or $1 \mathrm{~kg}$ of fresh FA tubers yielding $34.25 \times 10^{-3} \mathrm{~kg}$ of crude ethanol. Compared with cassava tubers $\left(1 \mathrm{~kg} \approx 0.08 \mathrm{~kg}\right.$ of crude ethanol (Adeoti, 2010) at an average of $809.3 \mathrm{~kg} / \mathrm{m}^{3}$ at $20{ }^{\circ} \mathrm{C}$ ), the crude ethanol from FA tubers was lower. Ethanol recovery ratio was about $60 \%$. Although there was a disparity between the stoichiometric ethanol content and ethanol recovery value, the recovery of ethanol indicates that the starch of FA was susceptible to enzymatic hydrolysis. The lack of agreement could be attributed to a number of factors which included the possibility of starch not getting converted into ethanol, possible variations in fermentation conditions, such as enzymes and yeast activity, and the presence of phytochemicals (for example, tannin) retarding microbial activities. Tannins are known to inhibit microbial activities (Chao et al., 2017, Sage et al., 2008), and their presence is capable of retarding the liquefaction (Li et al., 2015) as well as the fermentation process (Chao et al., 2017), thereby affecting ethanol yield. As shown in Table 10, FA tubers contained tannins and other phytochemicals (with oxalates constituting the major), some of which may get into the hydrolysis and fermentation process through the amounts contained in the starch granules. Also, enzymes concentration, temperature and time might have affected the rate of hydrolysing starch to hydrolysates (Ajibola et al., 2012), while some glucose might have been utilised by the yeast for the manufacture and maintenance of cell mass and in the formation of small amounts of glycerol as well as lactic acid (Borglum, 1980). However, while not a major consideration for this explorative study, understanding the optimum conditions for high ethanol production from FA tubers will require further research. At this stage, this study affirms the possibility of obtaining ethanol from FA tubers which is the aim of this study.

\subsection{Density of FA ethanol}

The quality of the ethanol to be blended with PMS is very important. Density is a key fuel property, which directly impacts engine performance. Fuel properties such as heating value and cetane number are related to density (Alptekin and Canakci, 2008). The injection systems of vehicles measure the fuel by volume, therefore any changes in fuel density may affect engine output power as a result of different mass of fuel injected (Alptekin and Canakci, 2008). From the analysis, the mean density of the crude FA ethanol was $801.2 \mathrm{~kg} / \mathrm{m}^{3}$ at $20^{\circ} \mathrm{C}$. For anhydrous ethanol, the Brazilian Ethanol Specifications Resolution ANP \#19 - 2015 has specified a maximum density limit of $791.5 \mathrm{~kg} / \mathrm{m}^{3}$ at $20^{\circ} \mathrm{C}$. Since the value obtained was higher, the presence of water and other elements might have influenced the density of the FA ethanol. Although the ethanol obtained was not dehydrated (being outside the scope of the present study), as illustrated in Table 11, FA tubers contained some appreciable amounts of elements, though low in vanadium, nickel, and copper. Potassium, followed by calcium, was the major constituent of all samples. How much of these elements (including the phytochemicals) were contained in the crude FA ethanol is difficult to explain at this stage. However, to be used as fuel grade, apart from the need to ensure that the amounts of sulphur, phosphorus, iron, sodium, and copper in the fuel ethanol are within limits, water also needs to be removed from the crude ethanol to meet the specification limits of $1.0 \%$ (maximum) by ASTM D 4806 or $0.3 \%$ 
(m/m) (maximum) by EN 15376 in ethanol.

\subsection{FA for fuel grade ethanol production programme in Nigeria}

As this study has illustrated, starch from FA offers some important opportunities. Considering the data in Tables 6 and 7, a substantial amount of carbohydrate in FA tubers was available during the dormancy period from October to March. No studies have indicated the peak period for FA carbohydrate content. This study also observed some reasonable amounts of carbohydrate in samples collected in March (Table 7), suggesting harvests could last until plant sprouts. The dormancy period had little effect on the carbohydrate contents of tubers (Tables 6 and 7). Starch from all parts of the existing stock of FA tubers appears to be useable, although S2 had the highest amount (Table 7). As a rough indication of the potential contribution of FA to fuel ethanol production in Nigeria, it is assumed one third of the currently available FA tubers could be harvested. Assuming an average conservative starch yield of $2 \mathrm{t} \mathrm{ha}^{-1}$, conversion efficiency of $0.4 \mathrm{~m}^{3} \mathrm{t}^{-1}$ of FA starch, the potential ethanol production from FA would be almost $0.8 \times 10^{6} \mathrm{~m}^{3}$. To become fuel grade, FA ethanol must meet the EN 15376 or the ASTM D4806 specifications. When these specifications are met, the FA ethanol can be used in most automotive spark-ignition engines without any modifications while maintaining engine performance. To realise this, future studies will need to analyse the constituents of anhydrous FA ethanol.

Despite the above, an unknown issue is whether FA can be economically exploited. This is because cultivating FA may require input costs in terms of planting, pesticides, fertilizers, and crop management. Harvesting may be expensive, because of the need to excavate the tubers. An important concern is whether existing farm and ethanol processing equipment can be easily deployed to harvest and process FA tubers, thereby escaping large investment capital. Although the complexity of fuel ethanol production process depends on the feedstock (Sánchez and Cardona, 2007), no techniques exist for processing FA tubers to fuel ethanol, making it difficult to guess these costs as well as the cost of producing $1 \mathrm{~m}^{3}$ of crude ethanol from FA tubers. Since the properties of starch are influenced by its biological origin (Afolayan et al., 2012), compared with corn, potato, and cassava starches, FA starch may be problematic to extract as it does not settle quickly in water. With fuel ethanol from cellulosic biomaterials becoming increasingly popular (Abbas and Ansumali, 2010), the 3 to $6 \%$ fibre content in the tubers (Table 6) could be available for cellulosic fuel ethanol production, thereby increasing the overall ethanol yield from FA. While it may be cheaper to produce fuel ethanol from whole FA tubers, the issue of phytochemicals (or antinutrients) becomes a factor for consideration. Similar to other tuber or root crops, such as, sweet potato (Mitiku and Teka, 2017), yam (Shajeela et al., 2011), and cassava (Shajeela et al., 2011), FA tubers were also rich in antinutrients (Table 10). Since details about the antinutrient contents of FA starch are less clear, this suggests that future research should explore the antinutrient contents of FA starch as well as the elemental contents. For example, according to Chao et al. (2017), the effect of tannins on ethanol yield becomes insignificant when tannin concentration is lower than $1 \mathrm{~kg} / \mathrm{m}^{3}$.

Table 10: Some phytochemical properties of FA tubers harvested in March $2018(\mathrm{~N}=3)$

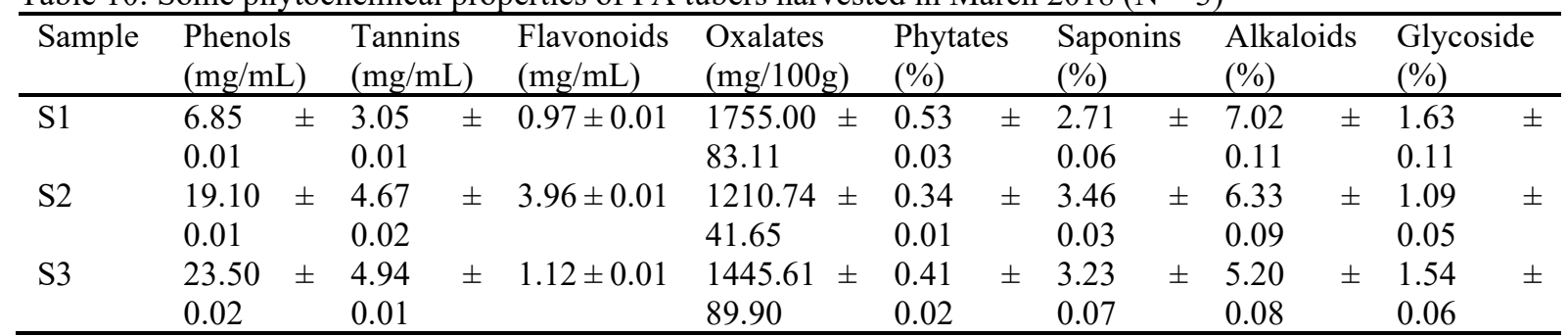

$1 \mathrm{mg} / \mathrm{mL}=1 \mathrm{~kg} / \mathrm{m}^{3}$ 
Table 11: Elemental composition (ppm) of FA tubers harvested in September $2017(\mathrm{~N}=3)$

\begin{tabular}{llll}
\hline Mineral & \multicolumn{2}{c}{ Sample } \\
\cline { 2 - 4 } & $\mathrm{S} 1$ & $\mathrm{~S} 2$ & $\mathrm{~S} 3$ \\
\hline $\mathrm{Na}$ & $6.4 \pm 1.5$ & $4.4 \pm 1.5$ & $18.6 \pm 2.8$ \\
$\mathrm{Mg}$ & $536.3 \pm 14.8$ & $441.2 \pm 14.6$ & $2864.7 \pm 30.4$ \\
$\mathrm{Al}$ & $64.8 \pm 3.6$ & $64.7 \pm 3.3$ & $158.9 \pm 7.6$ \\
$\mathrm{Si}$ & $227.3 \pm 4.1$ & $268.8 \pm 4.5$ & $885.4 \pm 8.1$ \\
$\mathrm{P}$ & $380.8 \pm 6.5$ & $212.1 \pm 6.6$ & $610.8 \pm 11.8$ \\
$\mathrm{~S}$ & $274.1 \pm 4.9$ & $190.1 \pm 5.1$ & $587.3 \pm 8.0$ \\
$\mathrm{Cl}$ & $253.3 \pm 4.2$ & $70.4 \pm 3.7$ & $1527.9 \pm 8.7$ \\
$\mathrm{~K}$ & $7213.7 \pm 16.6$ & $1661.2 \pm 8.6$ & $28996.6 \pm 31.9$ \\
$\mathrm{Ca}$ & $1939.6 \pm 25.6$ & $1781.3 \pm 11.2$ & $18070.6 \pm 77.7$ \\
$\mathrm{Ti}$ & $18.7 \pm 3.2$ & $9.0 \pm 2.6$ & $53.6 \pm 8.8$ \\
$\mathrm{~V}$ & $\mathrm{BDL}$ & $\mathrm{BDL}$ & $\mathrm{BDL}$ \\
$\mathrm{Cr}$ & $21.1 \pm 3.0$ & $17.4 \pm 2.5$ & $19.9 \pm 8.1$ \\
$\mathrm{Mn}$ & $6.9 \pm 3.3$ & $16.0 \pm 2.7$ & $112.2 \pm 9.7$ \\
$\mathrm{Fe}$ & $76.6 \pm 3.2$ & $49.6 \pm 2.6$ & $128.4 \pm 6.9$ \\
$\mathrm{Zn}$ & $3.0 \pm 1.8$ & $9.7 \pm 2.7$ & $9.1 \pm 4.0$ \\
$\mathrm{Ni}$ & $\mathrm{BDL}$ & $4.8 \pm 1.4$ & $\mathrm{BDL}$ \\
$\mathrm{Cu}$ & $\mathrm{BDL}$ & $1.2 \pm 1.5$ & $\mathrm{BDL}$ \\
$\mathrm{Sr}$ & $\mathrm{BDL}$ & $\mathrm{BDL}$ & $51.3 \pm 15.2$ \\
\hline
\end{tabular}

ppm indicates parts per million

BDL indicates below detection level

Another important uncertainty is the sustainability of FA exploitation for fuel ethanol production. The existing stock of FA has accrued over years, and may possibly sustain an appreciable amount of fuel ethanol production in the short term. This standing stock however will likely be consumed within one or two years. A sustained FA production will require plant breeding and cultivation, but it seems too premature to calculate production values as the agronomic behaviour of FA plants under cultivated farming is still unknown. As a first step, research would be needed to estimate plant yield in the first year and its fermentable carbohydrate (starch, glucose, fructose, maltose, and sucrose) contents, its fuel properties (in line with EN 15376 or ASTM 4808 specifications), the climate value of fuel grade ethanol production from FA in Nigeria, and whether FA can be cultivated on marginal lands which are not suitable for agricultural food crops. A preliminary investigation has shown that FA, like yams, could be cultivated from the tubers (from plot observations made up till September 2018). Similar to the ethanol programmes in Brazil and in the US (Elliott, 2008, Goldemberg, 2008, Ohimain, 2012), to build fuel ethanol industries around FA would also require substantial subsidies to get it off the ground. This may entail government providing soft loans to processors, moving the blend wall from E10 to E15, and the development of flexible fuel vehicles to further encourage fuel ethanol use as well as removing subsidies from fossil fuels.

\section{Conclusion and recommendation}

The paper has shown that FA could be a useful source of starch for fuel ethanol production, capable of replacing cassava mentioned in the 2007 NBPI which has food, feed and industrial value in Nigeria. To be exploited, additional studies are required on, for example, a detailed examination of the elemental and phytochemical properties of FA starch granules, how much fuel ethanol could be obtained from a cultivated hectare of FA tubers in the first year, and whether FA could be environmentally and economically cultivated, harvested, and processed. New planting, harvesting and processing techniques may have to be introduced, and the 2007 NBPI amended, especially if FA is expected to replace cassava. Because currently available FA plants have already amassed a large stock of carbohydrates, there seems to be reasonable justification to motivate the establishment of pilot schemes to explore the production of fuel grade ethanol from FA tubers in Nigeria. This challenge can be addressed by the NNPC under its renewable energy programmes (since the Biofuel Energy Commission is yet to be established) in collaboration with relevant research institutes in Nigeria. The intensification of biofuel programmes will help Nigeria in meeting some of its international environmental obligations by cutting $\mathrm{CO}_{2}$ emissions. In addition to this, producing fuel grade ethanol locally in Nigeria to mix with PMS will help to decrease the pump price of E10 PMS in Nigeria, currently between 1Akinkurolere, 2007 and 1Ovuakporie et al., $2015 \times 10^{3} \mathrm{Naira} / \mathrm{m}^{3}$. This study is also relevant to countries in the West African sub-region where FA is found.

\section{References}

Abbas A, Ansumali S (2010) Global potential of rice husk as a renewable feedstock for ethanol biofuel production. Bioenerg Res 3(4): 328-334 
Abila N (2010) Biofuels adoption in Nigeria - A preliminary review of feedstock and fuel production potentials. Manag Environ Qual Int J 21(6): 785-795

Adeoti O (2010) Water use impact of ethanol at a gasoline substitution ratio of $5 \%$ from cassava in Nigeria. Biomass Bioenergy 34: 985-992.

Adeoti O, Ayelegun TA, Oyewole BA (2009) Impact of gari consumption on the water resource of Nigeria. Afri J Biotechnol 8(25): 7283-7289

Adepoju AL, Adejumo BA (2015) Some proximate properties of sweet potato (Ipomoea Batatas L) as influenced by cooking methods. International Journal of Scientific and Technology Research 4(3):146-148

Ado SA, Olukotun GB, Ameh JB, Yabaya A (2009) Bioconversion of cassava starch to ethanol in a simultaneous saccharification and fermentation process by co-cultures of Aspergillus niger and Saccharomyces cerevisiae. Sci World J 4(1):19-22.

Afolayan MO, Omojola MO, Onwualu AP, Thomas S (2012) Further physicochemical characterization of Anchomanes difformis starch. Agric Biol J N Am 3(1): 31-38.

Agyare SC, Boakye YD, Apenteng JA, Dapaah SO, Appiah T, Adow A (2016) Antimicrobial and antiinflammatory properties of Anchomanes difformis (B1.) Engl. and Colocasia esculenta (L.). Biochem Pharmacol 5:1. DOI: 10.4172/2167-0501.1000201

Ajibola FO, Edema MO, Oyewole OB (2012) Enzymatic production of ethanol from cassava starch using two strains of saccharomyces cerevisiae. Niger Food J 30(2): 114-121

Akinkurolere RO (2007) Assessment of the insecticidal properties of Achomanes difformis (P. Beav.) powder on five beetles of stored produce. J Entomol 4(1): 51-55.

Akinoso R, Olatunde SJ (2014) Effect of mash quantity and roasting duration on some physical and pasting properties of gari. Int Food Res J 21(1):77-82.

Alatise OI, Obiajunwa EI, Lawal OO, Adesunkanmi ARK (2009) Particle-Induced X-ray Emission (PIXE) analysis of minor and trace elements in gallstones of Nigerian patients. Biol Trace Elem Res 134:13-24

Alptekin E, Canakci M (2008) Determination of the density and viscosities of bio-diesel-diesel fuel blends. Renew Energ 33: 2623-2630

Amoah RS, Sam-Amoah LK, Boahen CA, Duah F (2010) Estimation of the material losses and gari recovery rate during the processing of varieties and ages of cassava into gari. Asian J Agric Res 4(2): 71-79

Anderson ST, Elzinga A (2014) A ban on one is a boon for the other: Strict gasoline content rules and implicit ethanol blending mandates. J Environ Econ Manag 67: 258-273

Arshad M, Bano I, Younus M, Khan A, Rahman A (2018) Health concerns associated with biofuel production. In: Arshad M (ed) Perspectives on water usage for biofuels production - Aquatic contamination and climate change. Springer International Publishing AG, Switzerland

Association of Official Analytical Chemists (AOAC) (1990) Official methods of analysis $15^{\text {th }}$ ed. AOAC, Washington, D. C

Barakat Y, Awad EN, Ibrahim V (2015) Fuel consumption of gasoline ethanol blends at different engine rotational speeds. Egypt J Petrol 25: 309-315.

Ben-Iwo J, Manovic V, Longhurst P (2016) Biomass resources and biofuels potential for the production of transportation fuels in Nigeria. Renew Sust Energ Rev 63: 172-192

Bero J, Ganfon H, Jonville M-C, Frédérich M, Gbaguidi F, DeMol P, Moudachirou M, Quetin-Leclercq J (2009) In vitro antiplasmodial activity of plants used in Benin in traditional medicine to treat malaria. J Ethnopharmacol 122: 439-444

Borglum GB (1980) Starch hydrolysis for ethanol production. American Chemical Society meeting/2. Chemical Congress of the North American Continent, Las Vegas, NV, USA

Chao B, Liu R, Zhang X, Zhang X, Tan T (2017) Tannin extraction pretreatment and very high gravity fermentation of acorn starch for bioethanol production. Bioresour Technol 241: 900-907

Crago CL, Khanna M (2013) Carbon abatement in the fuel market with biofuels: Implications for second best policies. J Environ Econ Manag 67: 89-103

Dale B (2008) Biofuels: Thinking clearly about the issues. J Agric Food Chem 56: 3885-3891

das Neves MA, Kimura T, Shimizu N, Shiiba K (2006) Production of alcohol by simultaneous saccharification and fermentation of low-grade wheat flour. Braz Arch Biol Technol 49(3): 481-490

de Fraiture C, Giordano M, Liao Y (2008) Biofuels and implications for agricultural water use: blue impacts of green energy. Water Policy 10(suppl 1): 67-81

Dong F (2007) Food security and biofuels development: The case of China. Briefing Paper 07-BP52. Center for Agricultural and Rural Development, Iowa State University, Iowa

Eboh M (2017) I'll resign if we don't achieve self sufficiency in crude oil refining by 2019 - Kachikwu. Vanguard (Nigeria). https://www.vanguardngr.com/2017/05/ill-resign-dont-achieve-self-sufficiency-crude-oilrefining-2019-kachikwu/. Accessed 10 December 2017

Egwurugwu JN, Ohamaeme MC, Chinko BC, Ebuenyi MC, Akunneh-Wariso CC, Ngwu EE, Ugwuezumba PC, 
Ezekwe SR (2017) Effects of extracts of anchomanes difformis on haematological parameters of albino wistar rats. Int Res J Medical Sci 5(3): 1-6.

Elliott K (2008) Biofuels and the food price crises: A survey of the issues. Working Paper Number 151. Center for Global Development, Washington

Escobar JC, Lora ES, Venturini OJ, Yāñez EE, Castillo EF, Almazan O (2008) Biofuels: Environment, technology and food security. Renew Sust Energ Rev 13: 1275-1287

Essiet D (2017) Soaring with ethanol. The Nation (online). http://thenationonlineng.net/soaring-with-ethanol/. Accessed 1 February 2018

Ewing M, Msangi S (2008) Biofuels production in developing countries: assessing tradeoffs in welfare and food security. Environ Sci Policy 12: 520-528

Federal Republic of Nigeria (2007) Nigerian bio-fuel policy and incentives. NNPC, Abuja

Food and Agriculture Organisation of the United Nations (2019) Crops. http://www.fao.org/faostat/en/\#data/QC. Accessed 13 June 2019

Galadima A, Garba ZN, Ibrahim BM, Almustapha MN, Leke L, Adam IK (2011) Biofuels Production in Nigeria: the policy and public opinions. J Sustain Dev 4(4): 22-31

Global Edge (2017) Nigeria: Economy. https://globaledge.msu.edu/countries/nigeria/economy. Accessed 15 May 2017

Goldemberg J (2008) The Brazilian biofuels industry. Biotechnol Biofuels 1: 6. doi:10.1186/1754-6834-1-6

Hodge JE, Hofreiter BT (1962) Determination of reducing sugars and carbohydrates. In: Whistler RL, Wolfrom ML (eds) Methods in carbohydrate chemistry. Academic Press, New York, v1. pp. 380-394.

İçöz E, Tuğrul KM, İçöz E (2008) Research on ethanol production and use from sugar beet in Turkey. Biomass Bioenergy 33: 1-7.

Ifemeje JC, Egbuna C, Eziokwudiaso JO, Ezebuo FC (2014) Determination of the anti-nutrient composition of Ocimum gratissimum, Corchorus olitorius, Murraya koenigii Spreng and Cucurbita maxima. International Journal of Innovation and Scientific Research 3(2): 127-133

Jacob AE, MacDonald I (2015) Renal effects of Anchomanes difformis crude extract in wistar rats. Avicenna J Phytomed 5(1): 17-25.

Japan Automobile Manufacturers Association (2009) Quality of bio-ethanol and use of ethanol-blended gasoline. http://www.jama.or.jp/eco/wwfc/pdf/JAMA_FQ_PositionStatement_Ethanol.pdf. Accessed 21 September 2018

Kachikwu I (2017) Nigeria will stop fuel importation by 2019. Vanguard (Nigeria). https://www.vanguardngr.com/2017/02/nigeria-will-stop-fuel-importation-2019-kachikwu/. Accessed 10 December 2017

Larsen U, Johansen T, Schramm J (2009) Ethanol as a fuel for road transportation, main report. IEA-AMF. https://www.iea-amf.org/app/webroot/files/file/Annex\%20Reports/AMF_Annex_35-1.pdf. Accessed 14 June 2018

Leal MRLV, Valle TL, Feltan JC, Carvalho CRL (2014) Other raw materials for producing ethanol. In: Cortez LAB (coord) Sugarcane bioethanol - R\&D for productivity and sustainability. Editora Edgard Blücher, São Paulo. pp. 519-540. http://dx.doi.org/10.5151/BlucherOA-Sugarcane-SUGARCANEBIOETHANOL_47

Li J, Danao M-GC, Chen S-F, Li S, Singh V, Brown PJ (2015) Prediction of starch content and ethanol yields of sorghum grain using near infrared spectroscopy. J Near Infrared Spectrosc 23: 85-92

Lolas GM, Markakis P (1975) Phytic acid and other phosphorus compounds of beans (Phaseolus vulgaris L.). J Agric Food Chem 23(1): 13-15.

Loos PJ, Hood LF, Graham HD (1981) Isolation and characterisation of starch from breadfruit. Cereal Chem 58(4):282-286.

Mitiku DH, Teka TA (2017) Nutrient and antinutrient composition of improved sweet potato [Ipomea batatas (L) Lam] varieties grown in eastern Ethiopia. Nutrition and Food Science 47(3): 369-380. DOI 10.1108/NFS-072016-0098

Montagnac JA, Davis CR, Tanumihardjo SA (2008) Processing techniques to reduce toxicity and antinutrients of cassava for use as a staple food. Compr Rev Food Sci Food Saf 8: 17-27

National Bureau of Statistics (NBS) (2019) Nigerian gross domestic product report (Q4 \& Full Year 2018). NBS, Abuja

Naylor NL, Liska AJ, Burke MB, Falcon WP, Gaskell JC, Rozelle SD, Cassman KG (2007) The triple effect: Biofuels, food security and the environment. Environment 49(9): 31-43

Nnodim O (2017) Ondo, NNPC sign MoU on biofuel plant. The Punch (Nigeria), November 2, p. 30.

NNPC (2010) 2010 annual statistical bulletin - 1st Edition. NNPC, Abuja

NNPC (2011) 2011 annual statistical bulletin - 1st Edition. NNPC, Abuja

NNPC (2012) 2012 annual statistical bulletin - 1st Edition. NNPC, Abuja

NNPC (2013) 2013 annual statistical bulletin - 1st Edition. NNPC, Abuja 
NNPC (2014) 2014 annual statistical bulletin - 1st Edition. NNPC, Abuja

NNPC (2015) 2015 annual statistical bulletin - 1st Edition. NNPC, Abuja

NNPC (2016) 2016 annual statistical bulletin - 1st Edition. NNPC, Abuja

NNPC (2017) Monthly financial and operations report January 2017. NNPC, Abuja

NNPC (2018) Monthly financial and operations report December 2018. NNPC, Abuja

NNPC (2018) Monthly financial and operations report January 2018. NNPC, Abuja

NNPC (2019) Monthly financial and operations report January 2019. NNPC, Abuja

Nwabanne JT (2009) Drying characteristics and engineering properties of fermented ground cassava. Afri J Biotechnol 3(5): 873-876. https://doi.org/10.5897/AJB2009.000-9145

Nwachukwu ID, Simonyan KJ (2015) Some engineering properties of cassava tuber related to its peeling mechanization. Umudike Journal of Engineering and Technology 1(1):12-24.

Ocloo FCK, Ayernor GS (2010) Production of alcohol from cassava flour hydrolysate. J Brew Distilling 1(2): 1521

OECD/FAO (2015) Biofuels. In: OECD-FAO (eds) Agricultural outlook 2015. OECD, Paris. http://dx.doi.org/10.1787/agr_outlook-2015-13-en. Accessed 13 June 2019

O'Hair SK (1990) Tropical root and tuber crops. https:/hort.purdue.edu/newcrop/proceedings1990/v1-424.html. Accessed 24 July 2018

Ohimain EI (2010) Emerging bio-ethanol projects in Nigeria: Their opportunities and challenges. Energy Policy 38: 7161-7168

Ohimain EI (2012) Can the Nigerian biofuel policy and incentives (2007) transform Nigeria into a biofuel economy? Energy Policy 54: 352-359

Oke MA, Annuar MSM, Simarani K (2016) Mixed feedstock approach to lignocellulosic ethanol production prospects and limitations. Bioenerg Res 9: 1189-1203

Okpo SO, Ayinde BA, Ugwa ZI, Ching FP, Alonge PO, Udi OO (2011) Anti-ulcer activity of the aqueous extract of Achomanes difformis. Niger J Pharm Sci 11(1): 58-65

Olanlokun JO, Babarinde CO, Olorunsogo OO (2017) Toxicity of Anchomanes difformis, an antimalarial herb in murine models. European J Med Plants 20(3): 1-13

Olawale AK, Olakunle TP, Akinro EB, Yoyinoye AS, Olanrewaju SO, Ghazali MA (2013) Antimicrobial effects of Anchomanes difformis extract-pure honey mixture on microorganisms isolated from sputum. Int $\mathrm{J}$ Pharm Sci Invent 2(61): 39-42

Oshewolo S (2012) Designed to fail? Nigeria's quest for biofuel. Afro Asian Journal of Social Sciences 3(3.3): 115

Ovuakporie-Uvo O, Idu M, Eze GO, Ozolua RI (2015) Toxicological studies of Anchomanes difformis Blume (Araceae) using rats and mice. Int J Basic Clin Pharmacol 4(6): 1228-1234

Oyetayo VO (2007) Comparative studies of the phytochemical and antimicrobial properties of the leaf, stem and tuber of Achomanes difformis. J Pharmacol Toxicol 2(4): 407-410

Pimentel D, Patzek TW (2005) Ethanol production using corn, switchgrass, and wood; Biodiesel production using soybean and sunflower. Nat Resour Res 14(1): 65-76

Quintero JA, Cardona CA, Felix E, Moncada J, Higuita JC (2015) Techno-economic analysis of fuel ethanol production from cassava in Africa: The case of Tanzania. Afr J Biotechnol 14(45): 3082-3092

Renewable Fuels Association (2011) Fuel ethanol: Industry guidelines, specifications and procedures. http://www.ethanolrfa.org/wp-content/uploads/2015/10/Industry-Guidelines-Specifications-andProcedures.pdf. Accessed 23 July 2018

Renewable Fuels Association (2018) Ethanol and engines. http://www.ethanolrfa.org/issues/ethanol-engines/. Accessed 12 July 2018

Renewable Fuels Association (2019) Annual world fuel ethanol production. https://www.ethanolrfa.org/statistics/annual-ethanol-production/. Accessed 20 June 2019.

Sage RF, Coiner HA, Way DA, Runion GB, Prior SA, Torbert HA, Sicher R, Ziska L (2008) Kudzu [Pueraria montana (Lour.) Merr. Variety lobata]: A new source of carbohydrate for bioethanol production. Biomass Bioenergy 33:57-61

Sánchez ÓJ, Cardona CA (2007) Trends in biotechnological production of fuel ethanol from different feedstocks. Biores Technol 99: 5270-5295

Sarkar N, Ghosh SK, Bannerjee S, Aikat K (2011) Bioethanol production from agricultural wastes: An overview. Renew Energ 37:19-27.

Shajeela PS, Mohan VR, Jesudas LL, Soris PT (2011) Nutritional and antinutritional evaluation of wild yam (Dioscorea spp.). Trop Subtrop Agroecosyst 14: 723-730

Shapouri H, Salassi M, Fairbanks JN (2006) The economic feasibility of ethanol production from sugar in the United States. U.S. Department of Agriculture, Washington D. C.

Singleton VL, Orthofer R, Lamuela-Raventós RM (1999) Analysis of total phenols and other oxidation substrates 
and antioxidants by means of folin-ciocalteu reagent. Methods Enzymol 299: 152-178.

Sorda G, Banse M, Kemfert C (2010) An overview of biofuel policies across the world. Energy Policy 38: 69776988

Stein K (2007) Food vs biofuel. Journal of the American Dietetic Association 107(11): 1870-1878

Sugrue A (2008) Biofuel production and the threat to South Africa's food security. Wahenga Brief 11: 1-7

Tambe VD, Bhambar RS (2014) Estimation of total phenol, tannin, alkaloid and flavonoid in Hibiscus Tiliaceus Linn. wood extracts. J Pharmacogn Phytochem. 2(4): 41-47

Teye E, Abano EE (2012) Physical properties of two varieties of sweet potato grown in coastal savannah zone of Ghana. Int J Sci Nat 3(1):105-109

Timilsina GR, Shrestha A (2010) How much hope should we have for biofuels? Energy 36: 2055-2069

U. S. Energy Information Administration (2016) Country analysis brief: Nigeria. https://www.eia.gov/beta/international/analysis.php?iso=NGA. Accessed 14 August 2018. 